\title{
Low cortisol levels in blood from dairy cows with ketosis: a field study
}

Kristina B Forslund*1, Örjan A Ljungvall2 and Bernt V Jones ${ }^{1}$

\begin{abstract}
Background: An elevated plasma glucose concentration has been considered to be a potential risk factor in the pathogenesis of left-displaced abomasums (DA). Therefore the present study was performed to investigate if spontaneous disease (parturient paresis, metritis, ketosis etc) in dairy cows results in elevated concentrations of glucose and cortisol in blood as cortisol is the major regulator of glucose in ruminants.
\end{abstract}

Methods: Cortisol, insulin, $\beta$-hydroxybutyric acid (BHBA), non esterified fatty acids (NEFA), and serum calcium were analyzed in blood serum and glucose, in whole blood, from 57 spontaneously diseased cows collected at different farms. The cows were grouped according to the disease; parturient paresis, recumbent for other reasons, mastitis, metritis, ketosis, inappetance and others.

Results: No elevated concentrations of cortisol or glucose were found in cows with metritis and mastitis but both cortisol and glucose were elevated in cows stressed by recumbency. Cows with ketonemia (BHBA > $1.5 \mathrm{mmol} / \mathrm{l}) \mathrm{did}$ not have low concentration of glucose in blood but significantly low levels of cortisol. Some of these cows even had cortisol concentrations below the detection limit of the analysing method $(<14 \mathrm{nmol} / \mathrm{l})$.

Conclusions: The study gives patho-physiological support to the treatment strategies of ketosis, recommending glucocorticoids, insulin etc. However further studies of this problem are needed to understand why cows with ketosis have low levels of cortisol and normal levels of glucose. To what extent elevated cortisol and glucose levels in hypocalcemic and recumbent cows are involved in the ethiology and /or the pathogenesis of DA also will need further research.

\section{Background}

The reason for collecting field material to this study was a hypothesis that the known relation between stress and/or painful diseases in high yielding dairy cows and DA [1] may be mediated through a concurrent increased cortisol secretion leading to hyperglycaemia. Beside an increase in $\beta$-hydroxybuturate (BHBA), identified by LeBlanc et al. (2005) [2] as a possible metabolic predictor of DA in dairy cattle, an elevated plasma glucose level has been considered a potential risk factor for DA as hyperglycaemia has been shown to reduce the rate of abomasal outflow in dairy cows [3]. For many different reasons it was not possible to collect enough material to prove this hypothesis but when analysing the blood samples some of the results were interesting enough to be published.

* Correspondence: kristina.forslund@kv.slu.se

1 Department of Clinical Sciences, Box 7054, Faculty of Veterinary Medicine and Animal Sciences, SLU, S-750 07 Uppsala, Sweden

Full list of author information is available at the end of the article
In ruminants blood glucose regulation differs from the regulation in most mono-gastric animals. For example in humans, insulin is secreted after consumption of glucose but in ruminants there is a release of glucagon after fodder intake [4]. One regulator of glucose in ruminants is cortisol, which acts to increase gluconeogenesis from amino acids. In starving ruminants the gluconeogenesis is maintained by elevated levels of glucocorticoids [4].

In lactating ruminants the rate of hepatic gluconeogenesis and the relative concentrations of glycogenic precursors regulate the level of milk production $[5,6]$. The flow of glucose into the mammary gland is not dependent of insulin in ruminants $[7,8]$.

Cortisol is used as an indicator of stress and pain and elevated serum cortisol has been shown in calves castrated without local anaesthesia [9], in surgical stress in dairy cows [10], in endotoxin mastitis and metritis $[11,12]$, in cows suffering from inflammatory foot lesions [13] and in cows with hypocalcemia [14]. 
It can be hypothesized that the known relation between stressful periparturient diseases in high yielding dairy cows and DA [1] and the hyperglycaemia reducing the rate of outflow of abomasal fluid in dairy cows [3] may be mediated through a concurrent increased cortisol secretion leading to hyperglycaemia. This has, to our knowledge, not been previously studied.

The present study was undertaken to investigate possible associations between stressful and/or painful diseases in dairy cows and blood concentrations of glucose and cortisol and some other metabolites.

\section{Methods}

\section{Animals}

This study included 57 cows with spontaneous disease, prospectively recruited from the county of Uppland, Sweden. They were diagnosed suffering from either parturient paresis, mastitis, metritis, ketosis, recumbency, and others e.g. tetany, prolapsed uterus, laminitis and/or inappetance. The cows were housed at different farms and were in different stages of lactation. Following the call from a farmer the practitioner (one of the authors, Ö. L.) visited the farm and blood samples from the diseased cows were collected. The clinical examination was performed with history-taking, an ocular registration of general appearance, behaviour, body condition, respiration etc. Auscultations of heart, lungs, abdomen were performed and some percussion when indicated. All cows were checked for body temperature and udder health. The blood samples were drawn from the mammary vein using a Vacutainer (Becton, Dickinson, Franklin, NJ, USA) after the clinical examination but before initiation of treatments. The same veterinarian examined and diagnosed all sick animals in this study, took the blood samples and analyzed glucose at the farm before appropriate treatment was started. The recumbent cows with a suspicion of hypocalcaemia were treated with a $\mathrm{Ca}$-infusion (Calphon vet. Bayer health care. Göteborg, Sweden) and re-sampled after about $15 \mathrm{~min}$.

The dairy cows were grouped according to clinical diagnosis and concentration of calcium and $\beta$-hydroxybuturate (BHBA) in blood serum according to Radostits et al, (2007) [15] as outlined in Table 1.

The sampling procedure was approved by the Ethical Committee for Animal Experiments, Uppsala, Sweden, according to the Swedish Act of Animal Welfare, 87/88.

\section{Analytical methods}

The blood sample was analyzed immediately at the farm for glucose (Hemo-Cue, B-Glucosephotometer serial number 9540102191, Helsingborg, Sweden). The following blood serum components were determined at the clinical pathology laboratory of the Department of clinical sciences; non esterified fatty acids (NEFA) by an enzy- matic method (NEFA C, Waco chemicals, Neuss, Germany), $\beta$-hydroxybuturate (BHBA) also by an enzymatic method ( $\beta$-Hydroxybuturate, LiquiColor, Stanbio laboratory, Boerne, TX, USA). Serum total calcium (StCa) was analyzed by colourimetry (Konelab 30i chemistry analyser (Konelab corp, Espoo, Finland)). Cortisol was determined by a solid-phase RIA (DPC, Los Angeles, CA, USA, presently SMSD.) according to the manufacturer's instruction. The method has earlier been evaluated for use in bovine samples [16] (detection limit $14 \mathrm{nmol} / \mathrm{l}$, intra-assay CV 2.2-6.3\%,). For the purpose of statistical analysis concentrations of cortisol below detection limit were assigned a value of $7 \mathrm{nmol} / \mathrm{l}$. Insulin was determined by RIA (Linco Research, St Charles, MO, USA).

\section{Statistical methods}

The variables BHBA, glucose, insulin, cortisol and insulin/glucose were transformed to a logarithmic scale with base e prior to statistical analyses to get a normal distribution of the residuals sufficiently for the purpose of the analysis. The effect of clinical diagnosis on blood and serum components was analysed with a general linear regression model, with group of clinical diagnosis as the only explanatory variable. The model was validated by visual inspection of the distribution of the residuals and of identified outliers. Paired t-tests were used to study the effect of treatment of the paretic syndromes (parturient paresis and "recumbent" cow) on the blood and serum components.

\section{Results and Discussion}

Average values of blood and serum components in the different groups are given in Table 2. Twenty one of the diseased cows had very low concentrations of cortisol i.e. below the detection limit $(<14 \mathrm{nmol} / \mathrm{l})$. Five of these cows were in group IK (Inappetence and Ketosis, BHBA $\geq 1.5$ $\mathrm{mmol} / \mathrm{l}(5 / 7)$ ) and four in group I (Inappetence, BHBA < $1.5 \mathrm{mmol} / \mathrm{l}(4 / 5))$. The cortisol concentrations were highest in the samples from cows suffering from parturient paresis (mean $78.0 \mathrm{nmol} / \mathrm{l}$, group $\mathrm{PP}$ ) and recumbent cows (mean $96.7 \mathrm{nmol} / \mathrm{l}$, group $\mathrm{R}$ ). Both these groups had significantly higher $(\mathrm{p}<0.001)$ levels of cortisol than the rest of the cows. The low concentration of cortisol in group IK and I were significantly lower $(\mathrm{p}<0.03)$ than the cortisol level in group MA.

For the first time to our knowledge, low to not even measurable concentrations of cortisol have been shown in cows suffering from spontaneously occurring ketosis (BHBA > $1.5 \mathrm{mmol} / \mathrm{l}$ ) [15], but this was not accompanied by low concentrations of blood glucose $(>2.9 \mathrm{mmol} / \mathrm{l})$. Cows suffering from metritis, mastitis or other diseases causing pain had no elevated concentrations of cortisol or glucose in the blood. However, both cortisol and glucose were elevated in cows stressed by recumbency. 
Table 1: Grouping of diseased cows by diagnosis and blood serum concentration of calcium (S-tCa) and $\beta$ hydroxybuturate (BHBA)

\begin{tabular}{|c|c|c|c|c|c|c|}
\hline \multirow[b]{2}{*}{ Group } & \multirow[b]{2}{*}{$\begin{array}{l}\text { Number of } \\
\text { cows }\end{array}$} & \multirow[b]{2}{*}{ Clinical diagnosis } & \multirow[b]{2}{*}{$\begin{array}{l}\text { Lactation } \\
\text { number, } \\
\text { median } \\
\text { (range) }\end{array}$} & \multirow[b]{2}{*}{$\begin{array}{l}\text { Production } \\
\text { Cycle2, median } \\
\text { (range) }\end{array}$} & \multicolumn{2}{|c|}{$\begin{array}{l}\text { AVERAGE1 (95\% CONFIDENCE } \\
\text { INTERVAL) CONCENTRATION }\end{array}$} \\
\hline & & & & & S-tCa mmol/l & BHBA $\mathrm{mmol} / \mathrm{I}$ \\
\hline IK & 7 & $\begin{array}{l}\text { Inappetance and ketosis, } \\
\mathrm{BHBA}>1.5 \mathrm{mmol} / \mathrm{l}\end{array}$ & $\begin{array}{l}2 \\
(1 ; 6)\end{array}$ & $\begin{array}{l}26 \\
(22 ; 50)\end{array}$ & $\begin{array}{l}2.2 \\
(2.0 ; 2.4)\end{array}$ & $\begin{array}{l}4.5 \\
(2.9 ; 6.9)\end{array}$ \\
\hline I & 5 & $\begin{array}{l}\text { Inappetance, } \mathrm{BHBA}<1.5 \\
\mathrm{mmol} / \mathrm{l}\end{array}$ & $\begin{array}{l}5 \\
(2 ; 6)\end{array}$ & $\begin{array}{l}2 \\
(0 ; 200)\end{array}$ & $\begin{array}{l}2.1 \\
(1.4 ; 2.7)\end{array}$ & $\begin{array}{l}0.9 \\
(0.6 ; 1.5)\end{array}$ \\
\hline MA & 7 & Mastitis & $\begin{array}{l}4 \\
(2 ; 6)\end{array}$ & $\begin{array}{l}60 \\
(3 ; 250)\end{array}$ & $\begin{array}{l}2.3 \\
(1.8 ; 2.8)\end{array}$ & $\begin{array}{l}0.6 \\
(0.4 ; 0.9)\end{array}$ \\
\hline ME & 7 & Metritis & $\begin{array}{l}4 \\
(2 ; 4)\end{array}$ & $\begin{array}{l}4 \\
(3 ; 14)\end{array}$ & $\begin{array}{l}2.1 \\
(1.7 ; 2.5)\end{array}$ & $\begin{array}{l}1.4 \\
(0.7 ; 2.5)\end{array}$ \\
\hline PP & 12 & $\begin{array}{l}\text { Parturient paresis } \mathrm{S}-\mathrm{tCa}< \\
1.25 \mathrm{mmol} / \mathrm{l}\end{array}$ & $\begin{array}{l}5 \\
(2 ; 8)\end{array}$ & $\begin{array}{l}1 \\
(0 ; 60)\end{array}$ & $\begin{array}{l}0.9 \\
(0.8 ; 1.0)\end{array}$ & $\begin{array}{l}0.7 \\
(0.5 ; 0.9)\end{array}$ \\
\hline $\mathrm{R}$ & 11 & $\begin{array}{l}\text { Recumbent cows, } \\
\text { S-tCa }>1.25 \mathrm{mmol} / \mathrm{l} \text {, treated } \\
\text { with Ca.including prolapsed } \\
\text { uterus, diarrhoea }\end{array}$ & $\begin{array}{l}4 \\
(1 ; 8)\end{array}$ & $\begin{array}{l}2 \\
(-1 ; 200)\end{array}$ & $\begin{array}{l}1.6 \\
(1.4 ; 1.9)\end{array}$ & $\begin{array}{l}0.5 \\
(0.3 ; 0.9)\end{array}$ \\
\hline $\mathrm{O}$ & 8 & $\begin{array}{l}\text { Others, including laminitis, } \\
\text { tetany, vagus indigestion, } \\
\text { "cough", no diagnosis, } \\
\text { lymphadenitis }\end{array}$ & $\begin{array}{l}2 \\
(1 ; 5)\end{array}$ & $\begin{array}{l}55 \\
(1 ; 180)\end{array}$ & $\begin{array}{l}2.2 \\
(2.0 ; 2.4)\end{array}$ & $\begin{array}{l}0.8 \\
(0.3 ; 2.3)\end{array}$ \\
\hline
\end{tabular}

${ }^{1}$ Geometric means for BHBA, i.e. back-transformed from a logarithmic scale

2Days post partum

The accuracy in studies based on clinical cases may have a problem in the different clinicians' ability to specifically diagnose a disease. In this study it is a great advantage that the same clinician has determined the diagnoses, which to the main part later were verified by laboratory analyses.

Although group IK had ketosis (>1.5 mmol of BHBA) and a mean NEFA level of $0.8 \mathrm{mmol} / \mathrm{l}$ they were not hypoglycaemic, neither was group I. Both these groups had low concentrations of cortisol, which was not expected since "starving" ruminants should maintain the gluconeogenesis with elevated levels of glucocorticoids [4]. Also Moyes et al, [17] presented higher serum cortisol concentration in negative energy balanced cows compared to cows with an ad libitum diet. Peripheral cortisol concentrations exhibit weak circadian rhythms in lactating cows with periods around $120 \mathrm{~min}$ [18], still, in spite of the low number of cows in each group; there were significant differences in cortisol levels between the groups in this study. Cortisol is synthesized from cholesterol in the adrenal glands which can import cholesterol from low-density lipoproteins (LDL)-cholesterol by means of
LDL receptor mediated endocystosis or it can be synthesised de novo from acetate [19]. The milk production is driven by fodder such as for instance grain that produces glucose precursors in the rumen. Thus a lot of propionate and lactate is produced in rumen maybe on expense of acetate. Beerda et al [20] have shown that high yielding dairy cows have lower cortisol response to ACTH administration than low yielding cows. Lactation ketosis results from more factors than solely severe energy deficit [21]. One possible reason could be difficulties in synthesising cortisol when their energy demands increases in peak lactation.

Cortisol concentrations are said to peak sharply around parturition and decrease to the same level as prepartum concentrations after 3-5 days of lactation $[22,23]$ or increase in dairy cows a few days before parturition and then have a significant decrease around 10 days post parturition [22].

The serum cortisol levels were highest in serum from recumbent cows $(96.7 \mathrm{nmol} / \mathrm{l})$ and cows suffering from parturient paresis $(78.0 \mathrm{nmol} / \mathrm{l})$ in the present study. Both these groups had significantly higher $(\mathrm{p}<0.001)$ levels of 
Table 2: Overall means ${ }^{1}$ (95\% confidence interval) of blood and serum components in the different disease groups before treatment according to clinical diagnosis ${ }^{2}$, as estimated from linear regression model

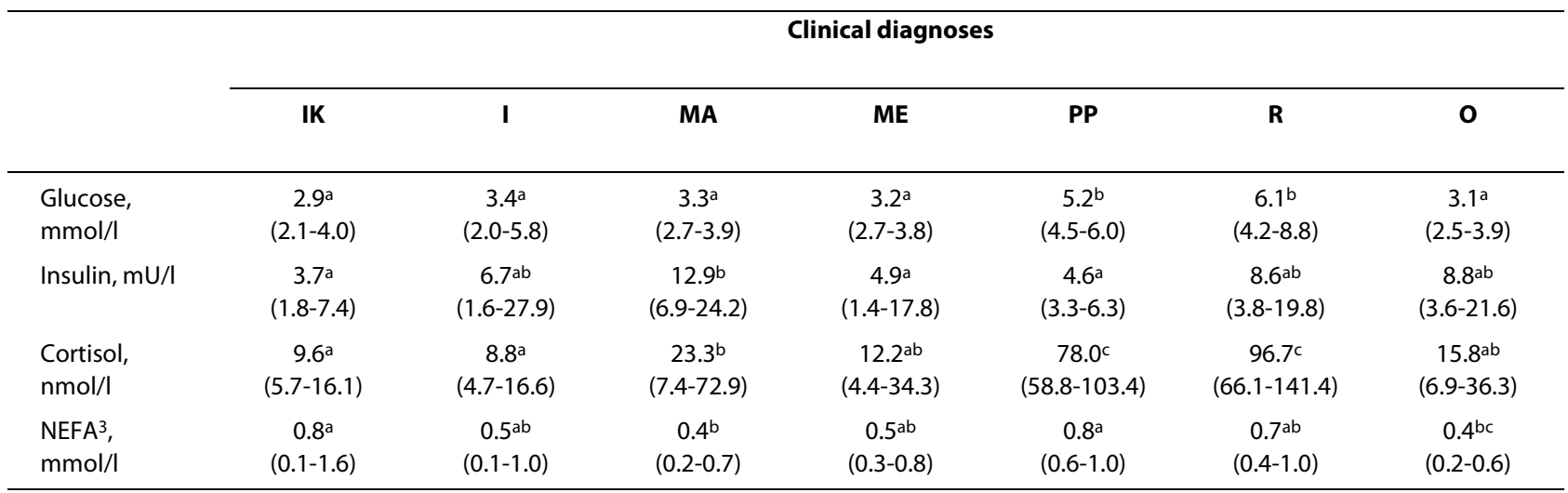

${ }^{1}$ Geometric means for glucose, insulin and cortisol, i.e. back-transformed from a logarithmic scale

2See Table 1 for definition of groups of clinical diagnoses

${ }^{3} \mathrm{NEFA}=$ Non-esterified fatty acids

Numbers within row with a common letter in the superscript does not differ significantly $(p>0.05)$.

cortisol than the rest of the cows and most of the cows in both these groups were close to parturition. Glucocorticoids also interfere with the absorption of $\mathrm{Ca}$ from the gastrointestinal tract [19]. The hypothesis that cows suffering from stress and/or painful diseases have elevated blood glucose levels due to an increase in serum cortisol could not be verified, as only cows suffering from paralysis (hypocalcaemia, group PP, and recumbent cows, group R) showed high blood glucose and serum cortisol concentrations compared to the others. The cows with hypocalcaemia (group PP) also had low concentrations of insulin despite the fact their levels of glucose were significantly higher than normal, indicating that they were unable to secrete insulin. This may be a result of the hypocalcaemia as insulin is secreted by a Ca-dependent exocytosis. After treatment with calcium solution the insulin levels were significantly $(\mathrm{p}<0.02)$ increased (Table 3). Cortisol has an indirect antilipolytic effect in vivo but do not aggravate or accelerate fatty degeneration of the liver [24]. Still, one of the most frequent necropsy findings in cows around parturition is fatty liver [15].

The cows with metritis and mastitis did not have higher blood concentrations of glucose than the other groups (Table 2). Nor did cows suffering from ketosis have decreased concentration of glucose. Reference values often differ between studies, due to different methods of analysis being used, but it is generally agreed that the blood glucose concentrations in dairy cows are higher before parturition than after [25]. However, in the present study cows with mastitis were in different stages of lactation and had significantly higher levels of insulin than the rest of the cows indicating that the pancreas in these animals was stimulated by more glucose eventually due to decreased glucose drainage to the udder.
Cows stressed by recumbency (groups PP and R) had significantly higher levels of cortisol and glucose. Elevated plasma cortisol during spontaneous hypocalcaemia in ruminants has also been shown previously by Horst and Jörgensen [26]. A relationship between milk fever and DA in cows has been described by van Dorp et al [27], and experimentally induced hyperglycaemia is reported to significantly reduce the rate of outflow of abomasal fluid in dairy cows [3]. The plasma glucose levels used in that experiment were similar to the ones observed in the PP and R in our study. If the hyperglycaemia at parturition seen in cows with parturient paresis is high enough to influence the abomasal emptying rate later in early lactation is hard to say. We have no further information about DA from the cows in our PP or R groups.

The BHBA concentration in blood (excluding group IK with $\mathrm{BHBA}>1.5 \mathrm{mmol} / \mathrm{l})$ was significantly higher $(\mathrm{p}<$ 0.03 ) in group ME (with an average of $1.4 \mathrm{mmol} / \mathrm{l}$ ) compared to group MA, (average $0.6 \mathrm{mmol} / \mathrm{l}$ ) and group PP. LeBlanc et al [2] identified metabolic predictors of DA in dairy cattle and found that an increased BHBA concentration was the best predictor compared to NEFA, glucose, urea, $\mathrm{Ca}$ and $\mathrm{P}_{\mathrm{in}}$. Metritis seems often to be a painful condition in cows with clinical signs as groaning, moaning and kicking the abdomen. In the present study we could not confirm any elevated concentrations of cortisol due to pain, but our study support, to a certain extent, LeBlanc et al [2] in their assumption that the BHBA might be a predictor of DA as metritis is considered to be one of several risk factors for DA [1].

The findings in this study of low cortisol concentrations in cows with clinical ketosis give a pathophysiological support to the treatment strategies of ketosis in veteri- 
Table 3: Overall means ${ }^{1}$ ( $95 \%$ confidence interval) of blood components before and after treatment of cows with parturient paresis and of "recumbent" cows ${ }^{2}$

\begin{tabular}{|c|c|c|c|c|}
\hline & \multicolumn{2}{|c|}{ Parturient paresis } & \multicolumn{2}{|c|}{ "Recumbent" cow } \\
\hline & Before & After & Before & After \\
\hline Glucose, $\mathrm{mmol} / \mathrm{l}$ & $\begin{array}{c}5.2^{\mathrm{a}} \\
(4.5 ; 6.0)\end{array}$ & $\begin{array}{c}5.8^{a} \\
(5.1 ; 6.6)\end{array}$ & $\begin{array}{c}6.1^{\mathrm{a}} \\
(4.2 ; 8.8)\end{array}$ & $\begin{array}{c}6.7^{\mathrm{a}} \\
(4.8 ; 9.5)\end{array}$ \\
\hline Insulin, mU/l & $\begin{array}{c}4.6^{a} \\
(3.3 ; 6.3)\end{array}$ & $\begin{array}{c}8.0^{\mathrm{b}} \\
(4.6 ; 14.2)\end{array}$ & $\begin{array}{c}8.6^{\mathrm{a}} \\
(3.8 ; 19.8)\end{array}$ & $\begin{array}{c}8.7^{a} \\
(4.0 ; 18.9)\end{array}$ \\
\hline Cortisol, nmol/l & $\begin{array}{c}78.0^{\mathrm{a}} \\
(58.8 ; 103.4)\end{array}$ & $\begin{array}{c}64.2^{\mathrm{b}} \\
(53.1 ; 77.6)\end{array}$ & $\begin{array}{c}96.7^{\mathrm{a}} \\
(66.1 ; 141.4)\end{array}$ & $\begin{array}{c}91.5^{\mathrm{a}} \\
(63.0 ; 133.1)\end{array}$ \\
\hline $\mathrm{NEFA}^{3}, \mathrm{mmol} / \mathrm{l}$ & $\begin{array}{c}0.8^{\mathrm{a}} \\
(0.6 ; 1.0)\end{array}$ & $\begin{array}{c}0.8^{\mathrm{a}} \\
(0.6 ; 1.0)\end{array}$ & $\begin{array}{c}0.7^{a} \\
(0.4 ; 1.0)\end{array}$ & $\begin{array}{c}0.7^{a} \\
(0.5 ; 0.9)\end{array}$ \\
\hline
\end{tabular}

${ }^{1}$ Geometric means for glucose, insulin and cortisol, i.e. back-transformed from a logarithmic scale

${ }^{2}$ See Table 1 for definition of the diagnoses

${ }^{3} \mathrm{NEFA}=$ Non-esterified fatty acids

Numbers within row and pair of columns with a common letter in the superscript does not differ significantly $(p>0.05)$

nary medicine textbooks recommending glucocorticoids. However further studies of this problem are needed to understand why cows with clinical ketosis do not eat and have low levels of cortisol.

\section{Conclusions}

No elevated concentrations of cortisol or glucose were found in cows with metritis and mastitis but both cortisol and glucose were elevated in cows stressed by recumbency. Surprisingly cows with ketosis (BHBA > $1.5 \mathrm{mmol} /$ 1) did not have low concentration of glucose in blood but significantly low levels of cortisol. Some of these cows even had cortisol concentrations below the detection limit of the analysing method $(<14 \mathrm{nmol} / \mathrm{l})$.

The study gives patho-physiological support to the treatment strategies of ketosis, recommending glucocorticoids. However further studies of this problem are needed to understand why cows with ketosis have low levels of cortisol and normal levels of glucose. To what extent elevated cortisol and glucose levels in hypocalcemic and recumbent cows are involved in the ethiology and/or the pathogenesis of DA also will need further research.

\section{Competing interests}

The authors declare that they have no competing interests.

\section{Authors' contributions}

KF initiated the study, contributed with the expertise in metabolic diseases in ruminants and was responsible for the manuscript preparation. ÖL collected the blood samples after diagnosing the cows and then analysed blood glucose. BJ was responsible for analyzing the rest of the blood serum components and contributed with expertise concerning those. All authors read and approved to the final manuscript.

\section{Acknowledgements}

The authors want to thank Professor Ulf Emanuelson for helping us with the statistical methods, preparing the tables and for the financial support as head of the division for the time being. We will also thank professor Paul Holtenius for letting us use the Hemo-Cue, B-Glucosephotometer (serial number 9540102191, Helsingborg, Sweden) and for his ideas around elevated glucose levels in relation to displacement of abomasum.

\section{Author Details}

'Department of Clinical Sciences, Box 7054, Faculty of Veterinary Medicine and Animal Sciences, SLU, S-750 07 Uppsala, Sweden and 2Kulterra AB, Rubens väg 7, S-740 21 Järlåsa, Sweden

Received: 1 February 2010 Accepted: 20 May 2010

Published: 20 May 2010

\section{References}

1. Rohrbach BW, Cannedy AL, Freeman K, Slenning BD: Risk factors for abomasal displacement in dairy cows. J Am Vet Med Assoc 1999, 214:1660-3.

2. LeBlanc SJ, Leslie KE, Duffield TF: Metabolic predictors of displaced abomasum in dairy cattle. J Dairy Sci 2005, 88:159-170.

3. Holtenius K, Sternbauer K, Holtenius P: The effect of plasma glucose level on abomasal function in dairy cows. J Anim Sci 2000, 78:1930-1935.

4. Trenkle A: Endocrine regulation of energy metabolism in ruminants. Fed Proc 1981, 40:2536-41.

5. Lomax MA, Baird GD: Blood flow and nutrient exchange across the liver and gut of the dairy cow. Effects of lactation and fasting. Br J Nutr 1983, 49:481-496.

6. Huntington GB: Energy metabolism in the digestive tract and liver of cattle: influence of physiological state and nutrition. Reprod Nutr Dev 1990, 30:35-47.

7. Zhao F-Q, Keating AF: Expression and regulation of glucose transporters in the bovine mammary gland. J Dairy Sci 2007, 90(E Suppl):E76-E86.

8. Nielsen MO, Madsen TG, Hedeboe AM: Regulation of mammary glucose uptake in goats: role of mammary gland supply, insulin, IGF-1 and synthetic capacity. J Dairy Res 2001, 68:337-349.

9. Thüer S, Mellema S, Doherr MG, Wechsler B, Nuss K, Steiner A: Effect of local anaesthesia on short- and long-term pain induced by two bloodless castration methods in calves. Vet J 2007, 173:333-42.

10. Mudron P, Scholz H, Sallmann HP, Rehage J, Kovac G, Bartko F, Holtershinken M: Effect of vitamin E injection on cortisol and white blood cell response to surgical stress in dairy cows. Int J Vitam Nutr Res 1994, 64:176-180.

11. Huszenicza G, Janosi S, Gaspardy A, Kulcsár : Endocrine aspects in pathogenesis of mastitis in postpartum dairy cows. Anim Reprod Sci 2004, 83:389-400. Review. 
12. Kulcsar M, Janosi S, Lehtolainen T, Kátai L, Delavaud C, Balogh O, Chilliard Y, Pyörälä S, Rudas P, Huszenicza Gy: Feeding-unrelated factors influencing the plasma leptin level in ruminants. Domest Anim Endocrinol 2005, 29:214-226. Review.

13. Almeida PE, Weber PS, Burton JL, Zanella AJ: Depressed DHEA and increased sickness response behaviors in lame dairy cows with inflammatory foot lesions. Domest Anim Endocrinol 2008, 34:89-99.

14. Waage S, Sjaastad OV, Blom AK: Plasma concentrations of cortisol in cows with hypocalcaemia in relation to their responses to treatment with calcium. Res Vet Sci 1984, 36:164-8.

15. Radostits OM, Gay CG, Hinchcliff KW, Constable PD, eds: Chapter 29, Metabolic Diseases. In Veterinary Medicine 10th edition. Saunders Elsevier; 2007:1613-1690.

16. Bolaños JM, Molina JR, Forsberg M: Effect of blood sampling and administration of ACTH on cortisol and progesterone levels in ovariectomized zebu cows (Bos indicus). Acta Vet Scand 1997, 38:1-7.

17. Moyes KM, Drackley JK, Salak-Johnson JL, Morin DE, Hope JC, Loor JJ: Dietary-induced negative energy balance has minimal effects on innate immunity during a Streptococcus uberis mastitis challenge in dairy cows during midlactation. J Dairy Sci 2009, 92:4301-4316.

18. Lefcourt AM, Bitman J, Kahl DS, Wood DL: Circadian and ultradian rhythms of peripheral cortisol concentrations in lactating dairy cows. $J$ Dairy Sci 1993, 76:2607-12.

19. Barret J: The adrenal gland (Chapter 49). In Medical Physiology Saunders, Elsevier Science; 2003. ISBN: 0-7216-3256-4.

20. Beerda B, Kornalijnslijper JE, Werf JT van der, Noordhuizen-Stassen EN, Hopster $\mathrm{H}$ : Effects of milk production capacity and metabolic status on HPA function in early postpartum dairy cows. J Dairy Sci 2004, 87:2094-102.

21. de Boer G, Trenkle A, Young JW: Glucagon, Insulin, Growth Hormone and Some Blood Metabolites During Energy Restriction Ketonemia of Lactating Cows. J Dairy Sci 1985, 68:326-37.

22. Goff JP, Kehrli ME Jr, Horst RL: Periparturient hypocalcemia in cows: prevention using intramuscular parathyroid hormone. J Dairy Sci 1989, 72:1182-1187

23. Patel OV, Takahashi T, Takenouchi N, Hirako M, Saski N, Domeki I: Peripheral cortisol levels throughout gestation in the cow: effect of stage of gestation and foetal number. Br Vet J 1996, 152:425-32.

24. Furll M, Jackel F: Effects of corticoids on parameters of lipid metabolism, hepatic metabolism, haematological parameters and milk yield in high-yielding cows in early lactation. Berl Munch Tierarzt/ Wochenschr 2005, 118:247-54

25. Holtenius K, Agenäs S, Delavaud C, Chilliard Y: Effects of feeding intensity during the dry period. 2. Metabolic and hormonal responses. J Dairy Sci 2003, 86:883-891.

26. Horst RL, Jorgensen NA: Elevated plasma cortisol during induced and spontaneous hypocalcaemia in ruminants. J Dairy Sci 1982, 65:2332-2337.

27. van Dorp RT, Martin SW, Shoukri MM, Noordhuizen JP, Dekkers CM: An epidemiologic study of disease in 32 registered Holstein dairy herds in British Columbia. Can J Vet Res 1999, 63:185-92.

\section{Submit your next manuscript to BioMed Central} and take full advantage of:

- Convenient online submission

- Thorough peer review

- No space constraints or color figure charges

- Immediate publication on acceptance

- Inclusion in PubMed, CAS, Scopus and Google Scholar

- Research which is freely available for redistribution

Submit your manuscript at www.biomedcentral.com/submit
C Biomed Central 